\title{
Наталія Гордієнко
}

Комунальний заклад вищої освіти «Хортищька національна навчально-реабілітаційна академія» Запорізької обласної ради

\section{Готовність випускників освітніх закладів інтернатного типу до соціальної самореалізації: емпіричний аналіз}

Метою статті є аналітичне викладення емпіричних даних щодо готовності випускників освітніх закладів інтернатного типу України до соціальної самореалізації у сучасних суспільно-економічних умовах.

Актуальність дослідження цієї проблеми зумовлене необхідністю науково-соціологічного супроводу процесу подальшої трансформації мережі освітніх закладів інтернатного типу, що є однією з головних реформ для вітчизняної системи загальної середньої освіти. Емпіричною основою науково-соціологічного супроводу мають бути дослідження освітньо-соціалізаційного потенціалу шкіл-інтернатів, спрямовані на грунтовний аналіз основних індикаторів готовності випускників освітніх закладів інтернатного типу до соціальної самореалізації в сучасних умовах.

Результати емпіричного дослідження, проведеного на базі 14 шкіл-інтернатів України, свідчать про те, що готовність до соціальної самореалізації більшою мірою демонструють старшокласники, базові ціннісні орієнтації яких відповідають типу постмодерної особистості - людини, життєва активність якої структурується за пріоритетами духовних, постматеріальних цінностей (розвиток власних здібностей, самореалізація; цікава і творча робота; здобуття вищої освіти; допомога іншим людям; життя згідно з релігійними заповідями). Встановлено, що старшокласники цього типу («постмодерни») у значно більшій мірі, ніж всі інші вихованці шкіл-інтернатів, прагнуть до кумуляції в майбутньому соціального капіталу (здобуття поваги серед людей, виявлення вдячності оточуючим за надану допомогу, розвиток взаємин з надійними друзями), досягнення у своєму житті високого рівня освіти, демонструють значно вищу готовність до самостійного життя після закінчення школи-інтернату, вищу довіру до власної сім'ї, до педагогів, до однокласників своєї та протилежної статі, а також мають значно вищу навчальну успішність на етапі завершення загальноосвітньої підготовки в умовах школи-інтернату. Старшокласники постмодерного типу меншою мірою схильні до проблемних, ризикованих сценаріїв поведінки в умовах школи-інтернату (раннього початку інтимного життя та булінгової поведінки).

Висновки проведеного дослідження стосуються можливостей оптимізації виконання школами-інтернатами освітньо-соціалізаційної місії щодо підготовки до соціальної самореалізації в сучасному суспільстві вихованців, значна частина яких перебуває у несприятливих життєвих і соціальних обставинах. Запропоновано концептуальні орієнтири для менеджерів освіти і педагогів щодо спрямування навчально-виховного процесу у школах-інтернатах на підготовку випускників постмодерного типу особистості.

Ключові слова: реформування шкіл-інтернатів, освітньо-соціалізаційний потенціал шкіл-інтернатів, соиіальна самореалізація молоді, особистість постмодерного типу, постмодерні иінності, виховна система иколи-інтернату, соціальний капітал випускників шкіл-інтернатів

\section{Natalia Gordienko}

Municipal Institution of Higher Education "Khortytsia National Educational and Rehabilitation Academy» of Zaporizhzhia Regional Council

\section{Readiness of boarding school leavers for social self-realization: empirical analysis}

The aim of the article is to analytically present empirical data on the readiness of Ukrainian boarding school graduates for social self-realization in the current socio-economic context.

The topicality of this research is determined by the need for scientific and sociological support of further transformations of the boarding school network which is one of the main reforms for the national system of general secondary education. This scientific and sociological support should be based on the study of the educational and social potential of boarding schools, aimed at a thorough analysis of the main indicators of readiness of boarding school graduates for social self-realization in present-day conditions.

The results of an empirical study conducted on the basis of 14 boarding schools in Ukraine show that a higher level of readiness for social self-realization is demonstrated by senior students whose basic value system corresponds to the type of postmodern personality, i.e. a person whose life activity is structured according to spiritual, post-material values (development of one's talents, self-realization; interesting and creative work; obtaining higher education; helping other people; living according to religious precepts). The study reveals that these senior students ("postmoderners") go far beyond other boarding school students in their aspiration to accumulate future social capital (gaining respect among people, showing gratitude to others www.grani.org.ua 
for their help, developing relationships with trusted friends), achieve a higher level of education in their lives, demonstrate a much higher readiness for independent life after leaving their boarding school, have higher trust in their own family, teachers, classmates of their own and the opposite sexes, and have a much higher academic performance at the final stage of gaining general education in a boarding school. Senior students of the postmodern type are less prone to problematic, risky behavioral scenarios in boarding schools (early onset of sexual activity and bullying behavior).

The conclusions of the study relate to the possibilities of optimizing the implementation of boarding schools' educational and socialization mission in terms of preparing students, most of whom experience unfavorable social circumstances, for social self-realization in the present-day society. The work provides some conceptual guidelines and practical recommendations for education managers and teachers in terms of aiming educational process in boarding schools at promoting the development of postmodern personality type among their students.

Keywords: reforming boarding schools, educational and socialization potential of boarding schools, social selfrealization of young people, postmodern personality, postmodern values, boarding school educational system, social capital of boarding school leavers

$\mathrm{O}$ днією з головних реформ системи освіти України, імплементація яких продовжуватиметься у 2021 p. i триватиме надалі, $\epsilon$ трансформація мережі освітніх закладів інтернатного типу, зокрема, суттєвескороченняїхньоїкількості,поступовий перехід від інституційного до сімейного догляду за дитиною, посилення ролі сім'ї як оптимального середовища для становлення та розвитку особистості. Зазначена реформа характеризується дискусійністю фахових оцінок раціональних масштабів скорочення мережі освітніх закладів інтернатного типу i суспільною поляризацію при обговоренні доцільності ліквідації багатьох цих закладів у кризовий період соціально-економічного розвитку України, прогнозована тривалість якого залишається невизначеною в ситуації поширення пандемії коронавірусу на міжнародному рівні.

Для об'єктивного наукового аналізу діаметрально протилежних аргументів щодо необхідності тимчасового збереження чи остаточної ліквідації системи шкіл-інтернатів слід враховувати показники результативності їхньої соціально-освітньої діяльності, зокрема, динаміку соціалізації вихованців, значна частина яких перебуває у несприятливих життєвих і соціальних обставинах, виступаючи потенційною групою ризику за критеріями девіантної соціалізації.

Основні характеристики процесу соціалізації вихованців закладів освіти інтернатного типу України досліджувалися вітчизняними вченими у взаємозв'язках iз проблемами підготовки вихованців до успішної життедіяльності у відкритому суспільстві, майбутнього самостійного життя, досягнення соціальної зрілості, формування адекватних соціальних установок, лікувальнореабілітаційного супроводу навчання дітей 3 особливими освітніми потребами, а також ресурсного (зокрема, матеріально-технічного і фінансового) забезпечення освітнього процесу у школах-інтернатах.

Результати дослідження проблеми формування життєвої компетентності учнів старших класів загальноосвітніх шкіл-інтернатів О. Кузьміна узагальнює в авторській концепції, основним теоретичним положенням якої $є$ інтерпретація суспільнофункціональної ролі закладів цього типу як тотального інституту соціалізації для дитини, сурогатної сім’і, школи та оточення (Кузьміна, 2011, с. 168). Виходячи з підсумків цього дослідження, можна констатувати, що впродовж тривалого періоду, визначального для успішної соціалізації, освітній заклад інтернатного типу виступає для вихованців уособленням життєвого простору, інтегруючи функції основних референтних груп і центрів комунікації: сім'ї, школи та групи однолітків, сприяючи набуттю не лише когнітивних, а й емоційно-смислових компонентів життєвого досвіду.

Ж. Петрочко зі співавторами приділяють увагу суттєвій залежності процесу соціалізації вихованців шкіл-інтернатів від успішності розв'язання адміністративними працівниками i педагогами низки значущих економічних, соціальних i психологічних проблем, які безпосередньо впливають на формування у випускників життєвих орієнтирів і соціальних установок (Вчимося жити самостійно, 2002, с. 3). Аналогічної дослідницької позиції дотримуються Л. Канішевська зі співавторами - науковими співробітниками Інституту 
проблем виховання Національної академії педагогічних наук України. За результатами системного аналізу роботи інтернатних закладів за напрямом підготовки учнів до життєдіяльності у відкритому суспільстві, автори зазначають, що інтегральний індекс самостійності в учнів інтернатних закладів $\epsilon$ нижчим, ніж у їхніх однолітків, які виховуються у сім'ї. Як наслідок, по закінченню школи-інтернату випускники не завжди мають адекватні уявлення про реальні труднощі дорослого життя, відчувають проблеми 3 адаптацією до нових умов самостійної побудови життєвої траєкторії (Канішевська та ін., 2013, с. 6). Враховуючи гостру необхідність вирішення цих проблем, науковці обгрунтували педагогічні умови підготовки старшокласників шкіл-інтернатів до життєдіяльності у сучасному відкритому суспільстві, запропонувалидієві формиіметоди педагогічної роботи для формування в учнів готовності до професійного самовизначення, свідомого ставлення до власного здоров'я, підготовки до сімейного життя, виховання в них психосоціальної суб'єктності та почуття власної гідності (Канішевська та ін., 2013).

Для соціологічної рефлексії процесу соціалізації вихованців шкіл-інтернатів значний пояснювально-інтерпретаційний потенціал має науковий концепт «соціальна зрілість», релевантність якого стосовно цієї категорії дітей $є$ очевидною. Аналізуючи цей концепт, Л. Канішевська констатує наявність недоліків у системі навчання і виховання, спрямованих на формування соціальної зрілості старшокласників шкіл-інтернатів. Авторка обгрунтовує необхідність докорінної модернізації парадигми виховання соціальної зрілості дітей-сиріт, забезпечення соціальнопедагогічних умов для реалізації їхнього потенціалу у різноманітних видах діяльності, які сприяють набуттю i примноженню соціально важливого досвіду (Канішевська, 1999 , c. 83 ).

При аналізі ступеня ефективності виконання школами-інтернатами покладених на них державою соціалізаційних функцій важливим науковим і практичним питанням $\epsilon$ реалізація комплексногопідходудо об'єктивної діагностики соціалізаційного потенціалу закладів цього типу. У цьому контексті подальшого використання заслуговує методика комплексного оцінювання, запропонована колективом українських науковців, які $\epsilon$ авторами аналітичного звіту «Життєвий шлях випускників інтернатних закладів, дитячих будинків сімейного типу та прийомних сімей» (Балакірєва та ін., 2010). Дослідники реалізували моніторингову процедуру, що інтегрує ряд ключових параметрів: наявність в учнів випускних класів соціальних зв'язків і дружніх відносин; уявлення про своє майбутнє; самооцінка учнями готовності до виходу на ринок праці та реальної трудової активності; спрямованість на продовження освіти; стан здоров'я, емоційно-психологічного благополуччя; наявність випадків насильства в закладах освіти інтернатного типу.

Наукові публікації свідчать про те, що проблеми соціалізації та інтеграції в суспільство вихованців освітніх закладів інтернатного типу нерозривно пов'язані i3 соціально-економічними реаліями, що зумовлюють пріоритетність задоволення базових життєвих потреб особистості, в першу чергу щодо успішного працевлаштування та наявності житла. На основі даних емпіричного аналізу О. Сидоренко доходить висновку, що старшокласники шкіл-інтернатів віком 16-18 років оцінюють себе готовими до самостійного життя в суспільстві на середньому рівні, вважають досить реальними свої можливості щодо вступу до закладу вищої освіти. Тривоги i побоювання старшокласників концентруються насамперед на проблемі житла. Автор доходить висновку, що одним iз основних чинників депривації випускників шкіл-інтернатів $є$ депривація власного простору, пов'язана з відсутністю реальних перспектив вирішення житлової проблеми (Сидоренко, 2013, с. 252).

Крім проблеми матеріального і фінансового забезпечення випускників, актуальною $\epsilon$ потреба модернізації матеріально-технічних умов, необхідних для успішного надання освітньо-соціалізаційних послуг дітям у період їхнього перебування у школі-інтернаті. О. Клименко за результатами вивчення практики інституціоналізації соціального захисту дітей в сучасному українському суспільстві констатує, що значна кількість закладів освіти інтернатного типу мають недостатне матеріально-технічне забезпечення, потребують ремонту не лише житлових, а й службових приміщень. Модернізації існуючої мережі шкіл-інтернатів сприяють останні 
зміни в державній соціальній політиці щодо пріоритетів і механізмів соціального захисту дітей, які перебувають у кризових ситуаціях і потребують додаткової соціально-педагогічної підтримки (Клименко, 2016, с. 327).

Комплексний науково-соціологічний аналіз проблеми соціалізації вихованців шкіл-інтернатів передбачає врахування й управлінського аспекту, що $є$ вирішальним для виправлення наявних недоліків у функціонуванні закладів цього типу та подальшої оптимізації їх діяльності на засадах інноваційного розвитку.

Механізм реформування закладів освіти інтернатного типу розкритий у монографії В. Нечипоренко, яка висвітлює досвід інноваційного розвитку санаторної загальноосвітньої школи-інтернату № 8 м. Запоріжжя, результатом якого стало переведення ii у нову функціональну якість - навчально-реабілітаційний центр. В. Нечипоренко зазначає, що ключовими перевагами навчально-реабілітаційних закладів, порівняно зі спеціальними школамиінтернатами, $\epsilon$ структурна завершеність i функціональна спеціалізація щодо здійснення реабілітаційного супроводу дітей на засадах системності та комплексності (Нечипоренко, 2013 , с. 4). Враховуючи контингент вихованців закладів освіти інтернатного типу, виключно важливою при цьому $\epsilon$ не тільки медична реабілітація, якої першочергово потребують діти з інвалідністю, а й соціальна, педагогічна і психологічна реабілітація, що є пріоритетною для вихованців 3 неблагополучних сімей, які перебувають у кризових життєвих обставинах.

В. Покась приділяє увагу трансформації філософської парадигми управління освітнім процесом шкіл-інтернатів України, що $\epsilon$ важливим чинником реформування їхньої діяльності. Вчений констатує, що на початку XXI ст. в Україні створено мережу інтернатних закладів різноманітних типів, що в цілому відповідають потребам населення. Враховуючи функціональне призначення шкіл-інтернатів, доцільною є реалізація в них менеджерами освіти моделей i технологій адаптивного управління через таку організацію навчально-виховного процесу, яка забезпечує адаптацію випускників до життєвих реалій. Організаційно-адаптивне управління школою-інтернатом як закладом освіти здійснюється через цілеспрямовану дію на колектив, окремих співробітників, вихованців, оптимальне використання ресурсів і засобів закладу 3 метою формування та розвитку в учнів навичок адаптації в сучасному суспільстві (Покась, 2012, с. 2). В. Покась зазначає, що оптимальні умови соціального становлення особистості в інтернатних закладах системи освіти створюються за наявності в них атмосфери співробітництва, партнерства й взаємодопомоги, чіткості визначення соціальних цілей. Крім цього, інтернатні заклади освіти мають великі потенційні можливості для поглибленої роботи 3 обдарованими й талановитими дітьми. Обдаровані учні в спеціалізованих інтернатних закладах системи освіти набагато швидше й більш інтенсивно реалізують свій інтелектуальний та творчий потенціал. Інтернатні заклади виконували й будуть виконувати в сучасних умовах соціальнопедагогічну функцію корекції, яка сприяє розв'язанню проблеми попередження девіантної поведінки дітей і підлітків (Покась, 2012, c. 28$)$.

На основі здійсненого аналізу наукової літератури можна констатувати, що проблематика соціалізації вихованців шкілінтернатів відображена у фаховому дискурсі комплексно і грунтовно, віддзеркалюючи як типові труднощі функціонування закладів цього типу в сучасному українському суспільстві, так i пріоритетні напрями ї реформування та системної модернізації 3 урахуванням соціально-освітньої місії. Разом i3 тим актуальними $€$ подальші емпіричні дослідження, спрямовані на більш детальний аналіз основних індикаторів готовності випускників освітніх закладів інтернатного типу до соціальної самореалізації в сучасних умовах, що характеризуються, з одного боку, невизначеністю суспільно-економічних перспектив, зростаючою орієнтацією молоді на трудову міграцію, поступовою девальвацією цінності вищої освіти і традиційної кар'єри у суспільній свідомості і одночасним поширенням у молодіжному середовищі установок щодо пошуку альтернативних варіантів швидкого нарощування фінансового та соціального капіталу, а 3 іншого боку актуалізацією значення навчання особистості протягом життя в процесі адаптації до динамічних змін на ринку праці, появою цілком нових життєвих шансів для 
соціального ліфту креативної молоді в періоди системного перезавантаження суспільних еліт, актуалізацією нових можливостей для географічної мобільності населення в умовах подальшої глобалізації, яка лише тимчасово загальмована карантинними обмеженнями на міжнародному рівні. У цьому контексті теоретико-методологічна цінність подальших досліджень проблеми соціалізаційного потенціалу шкіл-інтернатів у значній мірі залежить від урахування фахівцями зазначених трендів і відповідного оновлення соціологічної концепції ролі освітніх закладів цього типу на сучасному етапі розвитку українського суспільства 3 урахуванням здобутків i невирішених суперечностей 30-річного періоду реформування у незалежній Україні системи інституційного догляду та виховання дітей, які перебувають у складаних життєвих обставинах.

Враховуючи зазначене, мета статті полягає в аналізі емпіричних даних щодо готовності випускників освітніх закладів інтернатного типу до соціальної самореалізації у сучасних суспільно-економічних умовах.

Результати дослідження. В рамках соціологічного дослідження в 2019 р. нами було проведено анкетування 640 учнів 9-11 класів з 14 освітніх закладів інтернатного типу, які територіально охоплюють Запорізьку, Київську i Рівненську області. Всі інтернатні заклади підпорядковуються Міністерству освіти i науки України i обласним департаментам освіти і науки. За типом інтернатні заклади поділяються на загальноосвітні санаторні школи-інтернати (Запорізька загальноосвітня санаторнашкола-інтернат № 7, загальноосвітня санаторна школа-інтернат I-III ст. у структурі Хортицької національної навчальнореабілітаційної академії, Кам'янськоДніпровська загальноосвітня санаторна школа-інтернат, Бердянська загальноосвітня санаторна школа-інтернат, Матвіївська загальноосвітня санаторна школа-інтернат); інтернати для обдарованої молоді: гімназіїінтернати (Малобілозерська естетична гімназія-інтернат «Дивосвіт»), колегіумиінтернати (Січовий колегіум-інтернат), ліцеїінтернати (Мелітопольський педагогічний ліцей-інтернат «Творчість», Запорізький обласний ліцей-інтернат 3 посиленою військово-фізичною підготовкою «Захисник», Рівненський обласний науковий ліцей- інтернат); спеціальні загальноосвітні інтернати для дітей, які потребують корекції фізичного та (або) розумового розвитку (Кам'янська спеціальна загальноосвітня школа-інтернат); загальноосвітні школи-інтернати для дітейсиріт (Мелітопольська загальноосвітня школа-інтернат № 1); загальноосвітні школиінтернати (Чернігівська загальноосвітня школа-інтернат Запорізької обласної ради, Новомиколаївська загальноосвітня школаінтернат), Київська область (Володарська спеціалізована загальноосвітня школаінтернат II-III ступенів, Боярська спеціальна школа-інтернат I-II ступенів).

Запропонована респондентам анкета «Соціальна самореалізація особистості в сучасному суспільстві» складалася 3 двох блоків. Перший блок містив список 27 термінальних та інструментальних цінностей, найменування яких було складено нами 3 урахуванням досліджень І. Беха (Бех, 2003), О. Савчук (Савчук, 2012) і Л. Сокурянської (Сокурянська, 2015) щодо ціннісних засад освіти i соціалізації дітей та молоді в сучасному українському суспільстві. Другий блок анкети включав додаткові запитання, спрямовані на уточнення окремих емпіричних індикаторів, релеватних для аналізу ціннісної позиції респондентів (сприйняття проблемних ситуацій, які можуть траплятися у школіінтернаті; спрямованість життєвих планів; самооцінка готовності до самостійного життя та ін.).

Для більш глибокого наукового аналізу диференціації типів учнів, залежно від ціннісних орієнтацій, здійснено додаткові математико-статистичні розрахунки. Сформовано чотири групи, в які учнів розподілено згідно з максимальним значенням одного iз чотирьох чинників цінностей, наприклад, до групи «переважають духовні цінності» увійшли учні, для яких духовні цінності стоять на першому місці.

У результаті проведення факторизації виділено чотири основні фактори, з відсотком загальної дисперсії - 49,7\%. До масиву факторизаціїувійшливідповідідосліджуваних, які визначились із оцінками відповідних цінностей, відповіді «важко відповісти» не враховано. Із загальної кількості респондентів (640 вихованців шкіл-інтернатів) до масиву факторизації включено 472 особи.

Перший фактор, який ми назвали «Духовні 
цінності», описує 15,6\% загальної дисперсії та узагальнює такі ціннісні уявлення: «Розвиток своїх здібностей, самореалізація», «Цікава, творча робота», «Здобуття вищої освіти», «Допомога іншим людям», «Життя згідно 3 релігійними заповідями». Ці цінності відображають різні аспекти духовного життя: релігію, освіту, самовдосконалення, співчуття до інших людей. Їх об'єднує нематеріальний характер цінностей, їх духовний зміст.

Другий фактор, що позначений нами як «Досягальні цінності», описує 15,5\% загальної дисперсії та узагальнює такі аксіоконцентри: «Досягнення влади в суспільстві», «Накопичення багатства та високі доходи», «Досягнення високого становища в суспільстві» та «Створення власного бізнесу». Ці цінності об'єднує намагання людини досягти певних висот у матеріальному плані та посісти високі владні позиції в суспільстві. Ці цінності відповідають бажанням здійснити вертикальну соціальну мобільність.

Третій фактор, який ми співвідносимо 3 аксіомаркером «Спокійне життя», описує 9,7\% загальної дисперсії та узагальнює такі ціннісні пріоритети: «Спокійне життя, відсутність хвилювань, неприємностей», «Щаслива сім`я», «Наявність надійних друзів», «Здобуття поваги серед людей». Ці цінності об’єднує прагнення респондентів зайняти стабільну соціальну нішу середньої людини, яка задовольняється невисокими досягненнями в суспільстві, прагнучи забезпечити собі «нормальне життя» -без великих хвилювань, ризиків та надмірних зусиль.

Четвертий фактор, який ми назвали «Свобода та розваги», описує $8,9 \%$ загальної дисперсії та узагальнює такі ціннісні орієнтації: «Задоволення та розваги», «Особиста свобода, незалежність у судженнях та діях». Це цінності молодої людини сучасного суспільства 3 iї гедоністичними та ліберальними прагненнями. Менше, але досить вагомо, із цим фактором пов'язані також цінності спокійного життя та накопичення багатства. Безтурботні розваги заможної, вільної людини - ось життєве кредо представника такого типу особистості.

В процесі емпіричного аналізу все більш виразними ставали характерні відмінності ціннісного профілю респондентів, відповіді яких визначалися здебільшого першим фактором («Духовні цінності»), від інших профілів («Досягальні цінності»,
«Спокійне життя», «Свобода та розваги»). За результатами застосування альтернативних теоретичних підходів до пояснення цих типових відмінностей ми дійшли висновку про аналітико-інтерпретаційний потенціал концепту «особистість постмодерного типу», що дозволяє дати раціональне пояснення виявленим емпіричним фактам 3 єдиних теоретико-методологічних позицій, що $\epsilon$ прийнятними не тільки для соціологічної спільноти, але й у контексті сучасного міждисциплінарного дискурсу. Оскільки результати емпіричних досліджень проблеми готовності випускників освітніх закладів інтернатного типу до соціальної самореалізації $\epsilon$ виключно важливими для широкого суспільно-фахового діалогу з питань реформування системи освітніх закладів інтернатного типу, саме міждисциплінарна інтерпретація емпіричних даних $є$ важливою для вироблення консолідованої позиції менеджерів освіти, педагогів, соціологів, психологів та інших фахівців, дослідження яких $\epsilon$ важливими для розробки сучасної концепції реформування діяльності шкілінтернатів України у відкритому суспільстві європейського зразка.

Використовуючи міждисциплінарний концепт «особистість постмодерного типу» при емпіричному аналізі ціннісного профілю респондентів, відповіді яких переважно визначалися фактором «Духовні цінності», ми спиралися на наукові праці С. Костючкова (Костючков, 2019), М. Савчина (Савчин, 2015), В. Теремка (Теремко, 2014) i Т. Титаренко (Титаренко, 2010), які обгрунтовують теоретико-методологічні орієнтири інтерпретації сутнісних характеристик постмодерної особистості. Враховуючи цей міждисциплінарний теоретикометодологічний контекст, розглянемо специфічні емпіричні індикатори особистості цього типу, що сформувалася в умовах закладу освіти інтернатного типу. Для більш лаконічного термінотворення у подальшому тексті статті ми умовно називатимемо вихованців цього типу «постмодернами» для позначення їхніх суттєвих відмінностей від інших учасників дослідження, для яких цінність саморозвитку та самореалізації не $\epsilon$ першочерговою.

На основі емпіричного аналізу встановлено, що цінність здобуття вищої освіти є дуже 
важливою (займає одну з п’яти верхніх позицій ціннісної ієрархії) для 80\% постмодернів і лише для 52\% всіх інших респондентів.

Оцінка значущості сім'ї майже не залежить від прагнення до самореалізації: в обох групах оцінка ії̈ важливості відзначена на рівні близько 90\% (для постмодернів дещо вище - 90,6\%, тоді як для решти респондентів - 83,5\%).

Спокійне життя, відсутність хвилювань i неприємностей у більшій мірі цінуються постмодернами (відповідно, 52,6\% та 45,5\%), a накопичення багатства та високі доходи постмодернами цінуються менше, ніж іншими вихованцями шкіл-інтернатів (відповідно, $29,1 \%$ та 35,8\%). Також виявлено, що старшокласники цього типу у значно більшій мірі цінують професійну самореалізацію: цікаву, творчу роботу (відповідно, 66,2\% та $36 \%)$.

Теза про більшу значущість постматеріальних цінностей для постмодернів у порівнянні з іншими типами особистості підтверджується також і тими даними, що постмодернами значно більше цінується життя за релігійними заповідями (відповідно, $14,4 \%$ та 4,3\%), а також особиста свобода, незалежність у судженнях та діях (відповідно, $66,8 \%$ та $42 \%$ ).

В контексті емпіричного аналізу проблеми готовності випускників освітніх закладів інтернатного типу до соціальної самореалізації особливої уваги вимагають показники, що стосуються можливостей акумулювання соціального капіталу молоддю цієї категорії. В цілому, виявлено, що за ціннісними диспозиціями постмодерни мають більш сприятливі можливості для розвитку соціального капіталу, ніж решта респондентів. Здобуття поваги серед людей $є$ пріоритетною цінністю для 70,3\% постмодернів і лише для $52,2 \%$ інших респондентів. Значно більше за інших осіб постмодерни цінують допомогу іншим людям (відповідно, 53,7\% та 26,7\%) і наявність надійних друзів (85\% та 68,3\%).

При аналізі такого важливого аспекту соціального капіталу, як побудовані на довірі соціальні взаємини виявлено помітні відмінності між постмодернами та іншими респондентами за показниками: довіри до власної сім’ї (відповідно, 84,1\% та 76,6\%), довіри до педагогів (33,6\% та $16,5 \%)$, довіри до однокласників своєї статі (30,7\% та 15,5\%) і довіри до однокласників протилежної статі
(23,2\% та 8,6\%). Відповідаючи на додаткове запитання: «Які взаємини у Вас склалися між однокласниками?», варіант відповіді «Клас дружній» обрали 74,1\% постмодернів, тоді як серед інших респондентів - 64,5\%. Виявлені відмінності у сприйнятті респондентами соціально-психологічного клімату власного колективу свідчать про те, що постмодерни мають більшпозитивнівзаєминизоточуючими, $\epsilon$ більш доброзичливими і відкритими для спілкування. Це підтверджується також відповідями на запитання: «Чи плануєте Ви зустрічатися 3 однокласниками після закінчення інтернатного закладу?». Варіант відповіді «Так, планую зустрічатися часто» серед постмодернів відмітило значно більше респондентів (відповідно 49\% та 34,6\%).

Ще більш суттєві відмінності виявлені при порівнянні відповідей респондентів на додаткове запитання: «Чи багатьох Ваших вчителів Ви можете охарактеризувати позитивно?». Варіант відповіді «Майже всіх» частіше обрали постмодерни (67,5\% порівняно 3 46\% серед решти респондентів). Таким чином, ціннісний базис соціальної моралі позитивне сприйняття переважної більшості оточуючих - у постмодернів формується більш успішно, ніж у всіх інших респондентів.

Помітні відмінності між постмодернами та їхніми однолітками виявлені при аналізі відповідей респондентів на додаткові запитання, що стосуються можливих проблемних ситуацій в учнівських колективах шкіл-інтернатів. Так, при оцінці поширеності проблеми «Ранній початок інтимного життя» пункт «Ніколи не трапляється» значно частіше обирали постмодерни (40,9\% у порівнянні 3 $28,3 \%$ серед решти респондентів). Оцінюючи проблему «Байдужість педагогічних працівників», пункт «Ніколи не трапляється» також частіше обирали постмодерни (відповідно, 74,6\% та 55,1\%). «Знущання старших вихованців над молодшими» як актуальна проблема в учнівських колективах шкіл-інтернатів також по-різному сприймається постмодернами та їхніми однолітками. Пункт «Ніколи не трапляється» при оцінці частоти виникнення цієї проблеми обрали 78,7\% постмодернів і 59,4\% всіх інших респондентів.

Враховуючи той факт, що обидві умовні групи респондентів (постмодерни та інші учні) представлені досить пропорційно у 
контингенті закладів освіти інтернатного типу, що увійшли до емпіричної бази дослідження, виявлені відмінності можна пояснити меншою схильністю постмодернів до проблемних, ризикованих сценаріїв поведінки в умовах школи-інтернату. Саме таке пояснення $\epsilon$ найбільш імовірним для виявлених розбіжностей, коли, перебуваючи в одній школі-інтернаті, учні з різними типологічними характеристиками по-різному оцінюють ступінь актуальності окремих проблем внутрішньошкільного життя.

Дуже інформативною характеристикою особистості є іiі життєві плани, урахування яких передбачалося соціологічним дослідженням. Відповідаючи на проективне запитання: «Уявіть себе приблизно через 10 років. Якою особистістю Ви будете (хочете бути)?», варіант відповіді «Я отримаю вищу освіту» частіше обирали постмодерни, ніж всі інші респонденти (відповідно, 81,4\% та 64\%), натомість варіант «Я отримаю професійнотехнічну освіту» постмодерни обирали рідше, ніж інші (відповідно, 28,5\% та 44,6\%). Ці досить показові відмінності вказують на те, що постмодерни прагнуть досягти у своєму житті більш високого рівня освіти, вони в цілому більш впевнені у власному освітньому потенціалі. Так, варіант відповіді «Я матиму гарну роботу 3 нормальною заробітною платнею» частіше обрали постмодерни (відповідно, 93,5\% та 88,1\%).

Варіант відповіді «Я матиму автомобіль та інші життєво необхідні речі» 3 майже однаковою частотою обирали постмодерни та решта респондентів, 3 незначною перевагою у постмодернів (відповідно, 76,9\% та 71,7\%). Але варіант «Важко відповісти» постмодерни обирали рідше (відповідно 13,4\% та 16,8\%), що свідчить про їхні менші сумніви у своєму майбутньому матеріальному добробуті.

При характеристиці соціально значущих рис постмодерного типу особистості слід відзначити емпірично виявлену важливу особливість - старшокласники цього типу $\epsilon$ більшоптимістичниминетількищодо власного майбутнього, а й щодо майбутнього своїх однолітків. Даючи відповідь на запитання: «Яка частина Ваших однокласників, на Вашу думку, зможе влаштувати повноцінне життя після закінчення інтернатного закладу?», варіант «Вважаю, що всі зможуть влаштувати повноцінне життя», частіше обирали постмодерни (відповідно, 49,7\% та 36,4\%).

В контексті проблеми виконання закладами освіти інтернатного типу своєї функціональної місіїрелевантнимиє відповіді старшокласників на запитання: «Чи відчуваєте Ви готовність до самостійного життя після закінчення школиінтернату?». Пункт «Так, повністю готовий до самостійного проживання» обрали 72,4\% постмодернів і 51,6\% всіх інших респондентів, що свідчить про істотні відмінності між ними за рівнем впевненості у власному потенціалі щодо успішної життєпобудови.

Не менш важливою є також суб'єктивна оцінка старшокласниками ступеня власної ресурсної підготовленості до соціальної самореалізації. Відповідаючи на запитання: «Чи сформовані у Вас необхідні побутові вміння та навички для самостійного проживання після закінчення школиінтернату?», варіант відповіді «Необхідні навички сформовані у повній мірі» обрали $66,8 \%$ учнів постмодерного типу і $42,8 \%$ всіх інших респондентів. Якщо доповнити наведені емпіричні дані тим фактом, що постмодерни вчаться помітно краще за інших учнів (переважно високі бали мають, відповідно, 54\% і 34\%), то можна досить обгрунтовано стверджувати про вищу імовірність успішної соціалізації саме учнів постмодерного типу.

В контексті цілісного наукового аналізу психосоціального профілю постмодерного типу старшокласника школи-інтернату доцільно зазначити, що поширений суспільний стереотип про вирішальну роль фінансових ресурсів сім'ї для формування установки дитини на досягнення життєвого успіху (за принципом «бідні - бідніють, багаті - багатіють») $є$ досить умовним. Так, пункт «Моя сім'я досить заможна і матеріально забезпечена» відмітили майже 3 однаковою частотою постмодерни та решта респондентів (серед постмодернів таких дещо менше відповідно, 27,4\% та 31,3\%). Натомість, як 3'ясувалося, неочікувано більше значення має гендерний аспект, оскільки серед дівчат постмодернів більше, ніж серед хлопців (відповідно, 71,9\% і 63,8\%). Тим не менш, ці відмінності не $є$ настільки виразними, щоб констатувати ключову роль гендерного чинника у порівнянні з розглянутими вище соціокультурними детермінантами.

Проаналізовані результати емпіричного дослідження мають як теоретичне, так i 
практичне значення, оскільки, по-перше, доповнюють фактологічний базис сучасної концепції діяльності та розвитку школиінтернату як відкритої системи, функціонально здатної виконати суспільне замовлення щодо підготовки життєво компетентних i соціально успішних випускників, по-друге, можуть слугувати емпіричним підгрунтям для розробки практичних рекомендацій щодо спрямування навчально-виховного процесу у школах-інтернатах на підготовку випускників постмодерного типу особистості. Не претендуючи на повноту і вичерпність цих практичних рекомендацій, окреслимо нашу авторську позицію щодо доцільних пріоритетів спрямування навчально-виховного процесу на розвиток готовності випускників шкілінтернатів до соціальної самореалізації:

- розбудова не формально-імітаційної, а дієвої та ефективної системи учнівського самоврядування, в якій кожен вихованець школи-інтернату може знайти можливості для реалізації творчого потенціалу, соціальної компетентності та лідерських здібностей. Організація в системі самоврядування активної роботи різноманітних учнівських рад, секторів, профільних груп $є$ вагомим чинником знаходження кожною дитиною власної функціональної ролі, що відповідає їі інтересам і здібностям. Історико-педагогічний досвід свідчить про ефективність варіативних моделей самоврядування (наприклад, суттєво відрізняються організаційні моделі, розроблені та впроваджені педагогічними колективами інтернатних закладів під керівництвом А. Макаренка, Я. Корчака, В. СорокиРосинського), якщо адміністрація та педагоги дотримуються фундаментальних принципів опори на позитивне в дитині, колективної співтворчості та суб'єкт-суб'єктних відносин між усіма учасниками освітнього процесу;

- залучення вихованців шкілінтернатів до соціальної практики, яка доповнює традиційний навчальний процес різноманіттям суспільно значущих відносин, до яких залучаються діти, i актуального життєвого досвіду, який вони набувають. Участь у соціальних i волонтерських проєктах, акціях, ініціативах є можливістю для школярів цієї категорії суттєво розширити свій стандартизований комунікативний простір, відчути себе активним учасникам суспільного життя, застосувати набуті знання та компетентності. Як наслідок, школаінтернат стає для дитини вже не тільки місцем підготовки до майбутнього життя, а й простором активної життєтворчості, яка має особистий смисл і соціальне значення;

- суттєва інтенсифікація культурномистецьких впливів на становлення дитини як особистості постмодерного типу, носія цінностей духовно-постматеріального зразка («вічних цінностей»). Сучасний досвід шкіл-інтернатів свідчить про те, що такій культурно-мистецькій інтенсифікації сприяє перехід від кількісного підходу (нарощування кількості різноманітних виховних заходів, до яких залучаються вихованці) до якісного, що передбачає надання дітям можливостей для творчої самопрезентації і пошуку власного репертуару для культурного самовираження. Ефективною організаційною формою для цього може бути дитячий (молодіжний) театр, вистави якого синтезують різні види мистецтва для творчого самовираження вихованців. Класичні та сучасні зразки такої роботи доводять, що культурно-мистецький простір театру у структурі школи-інтернату може мати вирішальний вплив як на процес ресоціалізації дітей та молоді 3 досвідом асоціальної поведінки (досвід педагогічного колективу А. Макаренка), так і на динаміку формування соціально-культурної компетентності дітей 3 обмеженими можливостями здоров'я (проаналізований В. Нечипоренко (Нечипоренко, 2013) досвід педагогічного колективу санаторної школи-інтернату у структурі Хортицької національної академії щодо розбудови дитячого реабілітаційного театру «Інклюзив»).

\section{Висновки.}

Отже, результати анкетування 640 вихованцівшкіл-інтернатів Українидозволяють констатувати, що готовність до соціальної самореалізації в більшій мірі демонструють старшокласники, базові ціннісні орієнтації яких відповідають типу постмодерної особистості - людини, життева активність якої структурується за пріоритетами духовних, постматеріальних цінностей (розвиток власних здібностей, самореалізація; цікава i творча робота; здобуття вищої освіти; допомога іншим людям; життя згідно 3 релігійними заповідями). Старшокласники цього типу («постмодерни») у значно більшій мірі, ніж всі інші вихованці шкіл-інтернатів, прагнуть до 
кумуляції в майбутньому соціального капіталу (здобуття поваги серед людей, виявлення вдячності оточуючим за надану допомогу, розвиток взаємин 3 надійними друзями), досягнення у своєму житті високого рівня освіти, демонструють значно вищу готовність до самостійного життя після закінчення школи-інтернату, вищу довіру до власної сім'ї, до педагогів, до однокласників своєї та протилежної статі, а також мають значно вищу навчальну успішність на етапі завершення загальноосвітньої підготовки в умовах школи-інтернату. Крім того, старшокласники постмодерного типу у меншій мірі схильні до проблемних, ризикованих сценаріїв поведінки в умовах школи-інтернату (раннього початку інтимного життя та булінгової поведінки).

Враховуючи отримані емпіричні дані щодо більш сприятливих стартових можливостей випускників-постмодернів щодо соціальної самореалізації, оптимізації виконання школами-інтернатами освітньосоціалізаційної місії сприятиме спрямування навчально-виховного процесу на реалізацію таких пріоритетів: розбудова не формальноімітаційної, а дієвої та ефективної системи учнівського самоврядування; залучення вихованців шкіл-інтернатів до соціальної практики, яка доповнює традиційний навчальний процес різноманіттям суспільно значущих відносин і актуального життєвого досвіду; суттєва інтенсифікація культурномистецьких впливів на становлення дитини як особистості постмодерного типу, носія цінностей духовно-постматеріального зразка.

\section{БІБЛІОГРАФІЧНІ ПОСИЛАННЯ}

Балакірєва О. М., Чернін І. М., Хмелевська О. М. Аналітичний звіт «Життєвий шлях випускників інтернатних закладів, дитячих будинків сімейного типу та прийомних сімей» (за результатами соціологічного опитування). Київ : Український Інститут соціальних досліджень імені Олександра Яременка, Фонд Ріната Ахметова «Розвиток України», Український центр соціальних реформ, 2010. 106 с.

Бех І. Д. Виховання особистості : У 2 кн. Кн. 1 : Особистісно орієнтований підхід: теоретико-технологічні засади : навч.-метод. видання. Київ: Либідь, 2003. 280 с.

Канишевская Л. Специфика воспитания социальной зрелости учащихся школ-интернатов для детей-сирот. Соииология: теория, методы, маркетинг. 1999. № 4. С. 77-84.

Канішевська Л. В., Кузьменко Л. В., Свириденко С. О. Підготовка учнів інтернатних закладів до життєдіяльності у відкритому суспільстві. Кіровоград: Імекс-ЛТД, 2013. 336 с.

Клименко О. Ю. Особливості інституціоналізації соціального захисту дітей у кризових ситуаціях в сучасному українському суспільстві : дис. ... доктора соц. наук : 22.00.04. Харків, 2016. 418 с.

Костючков С.К. Проблемний ареал філософської антропології в епоху постмодерну: протиріччя і парадокси homo postmodernus. Метаморфози свободи у філософській антропологіï : VIII Міжнар. наук. конф. (м. Дніпро, 18-19 квітня 2019 р.). Дніпро: ДНУЗТ ім. академіка В. Лазаряна, 2019. С. 50-52.

Кузьміна О. В. Теоретичні аспекти формування життєвої компетентності учнів старших класів загальноосвітніх шкіл-інтернатів : монографія. Слов'янськ: Підприємець Маторін Б. І., 2011. 311 с.

Нечипоренко В. В. Системний розвиток навчально-реабілітаційного центру як відкритої інноваційної соціально-освітньої інституції : монографія. Запоріжжя: Видавництво Хортицького національного навчальнореабілітаційного багатопрофільного центру, 2013. $520 \mathrm{c}$.

Петрочко Ж. В. Вчимося жити самостійно. Київ: Державний інститут проблем сім’ї та молоді, 2002. 203 с.

Покась В. П. Зміна філософської парадигми управління навчально-виховним процесом інтернатних закладів освіти України: автореф. дис. на здобуття наук. ступеня доктора філос. наук: спец. 09.00.10 «Філософія освіти». Київ, 2012. 34 с.

Савчин М. В. Проблема особистості у постмодерністській психології. Особистість у розвитку: психологічна теорія і практика: монографія / за ред. С. Д. Максименка, В. Л. Зливкова, С. Б. Кузікової. Суми: Вид-во СумДПУімені А. С. Макаренка, 2015. С. 107-127.

Савчук О. В. Динаміка ціннісних орієнтацій української молоді. Актуальні проблеми соціології, психології, педагогіки. 2012. Вип. 16. С. 60-67.

Сидоренко О. А. Соціально-психологічний портрет випускників інтернатних закладів. Теоретичні $i$ прикладні проблеми психологї̈. 2013. № 3. С. 248-255.

Сокурянская Л. Г. Ценностные ориентации подростковой молодежи пограничья Центральной и Восточной Европы (по результатам международного исследования). Методологія, теорія та практика соціологічного аналізу сучасного суспільства. 2015. Вип 21. С. 251-258. Харків: Вид. центр ХНУ ім. В. Н. Каразіна

Теремко В. Людські виміри медіареальності постмодерну. Збірник пращь Науково-дослідного інститу пресознавства. 2014. Вип. 4. С. 253-275.

Титаренко Т. М. Постмодерна особистість у динаміці самоконституювання. Актуальні проблеми психології: Психологічна герменевтика. 2010. Т. 2. Вип. 6. С. 5-14. Київ. 


\section{REFERENCES}

Balakirjeva, O. M., Chernin, I. M. \& Khmelevsjka, O. M. (2010). Analitychnyi zvit «Zhyttievyi shliakh vypusknykiv internatnykh zakladiv, dytiachykh budynkiv simeinoho typu ta pryiomnykh simei» (za rezultatamy sotsiolohichnoho opytuvannia) [Analytical report "The life path of graduates of boarding schools, family-type orphanages and foster families" (based on the results of a sociological poll)]. Kyiv: Oleksandr Yaremenko Ukrainian Institute for Social Research, Rinat Akhmetov Foundation for Development of Ukraine, Ukrainian Center for Social Reforms [in Ukrainian].

Bekh, I. D. (2003). Vykhovannia osobystosti. Osobystisno oriientovanyi pidkhid: teoretyko-tekhnolohichni zasady [Upbringing of personality. Personally Oriented Approach: Theoretical and Technological Foundations]. Kyiv: Lybidj [in Ukrainian].

Kanishevsjka, L. V., Kuzjmenko, L. V. \& Svyrydenko, S. O. (2013). Pidhotovka uchniv internatnykh zakladiv do zhyttiediialnosti u vidkrytomu suspilstvi [Training of boarding schools pupils for life in an open society]. Kirovograd: Imeks-LTD [in Ukrainian].

Kanishevskaya, L. (1999). Spetsyfyka vospytanyia sotsyalnoi zrelosty uchashchykhsia shkol-ynternatov dlia deteisyrot [Specificity of upbringing the social maturity of pupils in boarding schools for orphans]. Sociology: theory, methods, marketing, 4, 77-84 [in Russian].

Klymenko, O. Ju. (2016). Osoblyvosti instytutsionalizatsii sotsialnoho zakhystu ditei u kryzovykh sytuatsiiakh v suchasnomu ukrainskomu suspilstvi [Features of institutionalization of social protection of children in crisis situations in modern Ukrainian society]. Doctor`s thesis. Kharkiv [in Ukrainian].

Kostjuchkov, S. K. (2019). Problemnyi areal filosofskoi antropolohii v epokhu postmodernu: protyrichchia i paradoksy homo postmodernus. Metamorfozy svobody u filosofskii antropolohii [The problem area of philosophical anthropology in the postmodern era: contradictions and paradoxes of homo postmodernus. Metamorphoses of freedom in philosophical anthropology]. Proceedings of the VIII International Scientific Conference. Dnipro: DNURT named after academician V. Lazaryan, 50-52 [in Ukrainian].

Kuzjmina, O. V. (2011). Teoretychni aspekty formuvannia zhyttievoi kompetentnosti uchniv starshykh klasiv zahalnoosvitnikh shkil-internativ [Theoretical aspects of the formation of life competence of high school students in boarding schools]. Slov'jansjk: Employer Matorin B. I. [in Ukrainian].

Nechyporenko, V. V. (2013). Systemnyi rozvytok navchalno-reabilitatsiinoho tsentru yak vidkrytoi innovatsiinoi sotsialno-osvitnoi instytutsii [Systematic development of the educational and rehabilitation center as an open innovative social and educational institution]. Zaporizhzhia: Publishing House of Khortytsia National Educational and Rehabilitation Center [in Ukrainian].

Petrochko, Zh. V. (2002). Vchymosia zhyty samostiino [We learn to live independently]. Kyiv: State Institute of Family and Youth Problems [in Ukrainian].

Pokasj, V. P. (2012). Zmina filosofskoi paradyhmy upravlinnia navchalno-vykhovnym protsesom internatnykh zakladiv osvity Ukrainy [Changing of the philosophical paradigm of managing the educational process of boarding schools in Ukraine]. Extended abstract of Doctor`s thesis. Kyiv [in Ukrainian].

Savchuk, O. V. (2012). Dynamika tsinnisnykh oriientatsii ukrainskoi molodi [Dynamics of value orientations of Ukrainian youth]. Actual problems of sociology, psychology, pedagogy, 16, 60-67 [in Ukrainian].

Savchyn, M. V. (2015). Problema osobystosti u postmodernistskii psykholohii. Osobystist u rozvytku: psykholohichna teoriia i praktyka [The problem of personality in postmodern psychology]. Personality in development: psychological theory and practice. Sumy: Publishing House of Sumy State Pedagogical University named after A. S. Makarenko, 107-127 [in Ukrainian].

Sokuryanskaya, L. G. (2015). Tsennostnye oryentatsyy podrostkovoi molodezhy pohranychia Tsentralnoi y Vostochnoi Evropy (po rezultatam mezhdunarodnoho yssledovanyia [Value orientations of adolescent youth in the borderlands of Central and Eastern Europe (based on the results of an international study)]. Methodology, theory and practice of sociological analysis of the current society, 21, 251-258 [in Russian].

Sydorenko, O.A. (2013). Sotsialno-psykholohichnyi portret vypusknykiv internatnykh zakladiv [Socio-psychological character of graduates of boarding schools]. Theoretical and applied problems of psychology, 3, 248-255 [in Ukrainian].

Teremko, V. (2014). Liudski vymiry mediarealnosti postmodernu [Human dimensions of postmodern media-reality]. Collection of works of the Research Institute of Press Studies, 4, 253-275 [in Ukrainian].

Tytarenko, T. M. (2010). Postmoderna osobystist u dynamitsi samokonstytuiuvannia [Postmodern personality in the dynamics of self-constitution]. Current problems of psychology: Psychological hermeneutics, 6, 5-14 [in Ukrainian].

\section{Gordienko Natalia}

Dr.Sc., Assoc. Prof., https://orcid.org/0000-0002-2636-0413,natali_zp_@ukr.net

Стаття надійшла / Article arrived: 09.02.2021

Схвалено до друку / Accepted: 15.03.2021 